\title{
Construction of the Linkage Mechanism of School and Government and Promote the Integration of Teacher Education -----With the Construction of Shandong Province, Weifang University Teacher Education Base as an Example
}

\author{
Binlu Feng ${ }^{1}$, Zhenguo $\mathrm{Qu}^{2}$, Chenming $\mathrm{Wei}^{2}$, and Tiansi $\mathrm{Li}^{3}$ \\ ${ }^{1)}$ University Office, Weifang University, Weifang, Shandong, China \\ ${ }^{2)}$ Teacher Education College, Weifang University, weifang, Shandong, China \\ ${ }^{3)}$ Office of Teaching Affairs, Weifang University, weifang, Shandong, China
}

Abstract - The integration of teacher education has become the general trend of the world teacher education reform. Compared with the foreign teacher education integration reform and practice focused on "school and school co-construction", our country pays more attention to the construction of teacher education base and focuses on the "school and government co-construction". Strengthen the construction of teacher education base is an effective way to realize the integration of teacher education; the subject of the construction of teacher education base is colleges, the key is the government, and the foundation is the mechanism and the system of school and government co-construction. Based on the construction of Shandong Province Weifang University teacher education base as an example, the article introduces the practice, thinking and the exploration on the construction of linkage mechanism in this base from the three aspects of the establishment of government promoting mechanism, the linkage mechanism of teaching and research and the linkage mechanism of development and training.

Keywords - teacher education, teacher education base, school and government co-construction, linkage mechanism

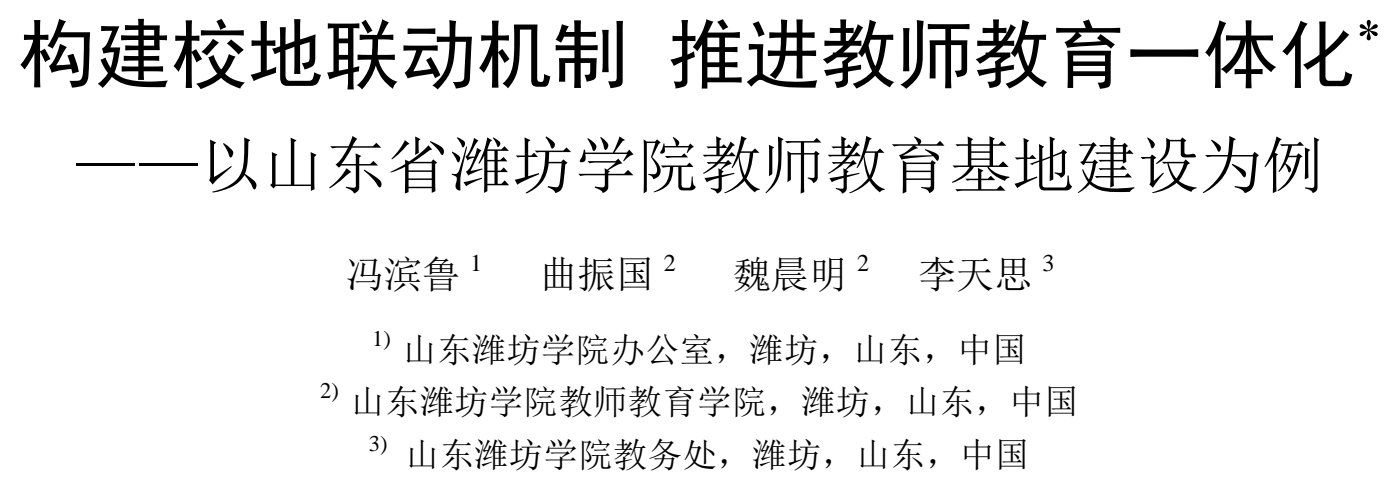

摘 要 教师教育一体化已经成为世界各国教师教育改革的总趋势。国外教师教育一体化改革和实践比较注重 “校校共建”, 我国 更加注重教师教育基地建设, 注重 “校地共建”。加强教师教育基地建设是实现教师教育一体化的有效途径; 教师教育基地建设的主体 是高校, 关键在地方, 根本是 “校地共建” 的机制和体制。本文以山东省潍坊学院教师教育基地建设为例, 从建立行政推进联动机制、 教学研究联动机制和培养培训联动机制三个方面介绍了该基地在构建校地联动机制方面的探索、实践与思考。

关键词 教师教育，教师教育基地，校地共建，联动机制

* 山东省高等学校教学改革项目 “高校教师教育与区域基础教育联动机制研究” 支持（项目编号 2012473） 


\section{1. 问题的提出}

教师教育一体化以终身教育思想为指导, 自 20 世纪 70 年代开始在国外兴起, 80 年代以来已经成为各国教师教 育的理念并逐渐在实践中实施与完善。

从国外看, 20 世纪 80 年代中期美国建立了专业发展 学校 (Professional Development School, 简称 PDS), 作为 教师教育的全新模式, 把教师职前培养和在职培训提高连 为一体, 中小学教师和大学教师共同负责师范生的培养和 指导。日本 1997 年制定了 “日本教育职员养成审议会” 制 度, 要求各行政及教育机关改善教师培训的内容和方法, 注重教师教育的整体性和连接性。英国政府为改变教师职 前职后相互割裂、缺少沟通、严重脱节的问题, 推出了教 师 “入职简介” 制, 建立新教师成长档案, 记录教师已经 接受的训练和主要优缺点, 注重教师专业成长的整个历程。

从国内看, 20 世纪 80 年代中期, 河北唐山师专和唐 山教育学院合并, 开创了地级教育学院与师专合并的首创 之举, 这也标志着我国在对教师教育一体化进行理论探讨 的同时, 也开始实践方面的改革和探索。进入 90 年代以后, 一些省级教育学院与有关高师院校先后合并, 为此教育部 在 1999 年 3 月 16 日颁布的《关于师范院校布局结构调整 的几点意见》中明确提出了职前职后教育贯通的目标。进 入 21 世纪后, 我国教师教育一体化发展和改革体现出新的 时代特征。建设国家级、省级和县级 “三级” 教师教育基 地是这一时期的突出特点, 加强 “校地共建” 是教师教育 基地建设的首要的和最重要的任务。

综上所述, 国外教师教育一体化的改革和实践比较注 重 “校校共建” (如美国) 以及高校主体作用的发挥 (如英 国、日本等); 我国在注重高师院校主体作用发挥的同时, 更加注重教师教育基地建设, 更加注重 “校地共建”。加强 教师教育基地建设是实现教师教育一体化的有效途径; 教 师教育基地建设的主体是高校, 关键在地方, 根本是 “校 地共建”的机制和体制。

在校地共建过程中, 怎样做到校地协调一致, 提高效 率效益, 而不仅仅停留在合作、互动、相互服务的层面? 山东省潍坊学院教师教育基地在构建校地 “联动” 机制方 面, 进行了一定的探索和实践, 取得了较好效果。

\section{2. 构建校地联动机制的实践与探索}

“联动” 不是 “互动”, 也不是简单的 “合作”。“互动” 是指双方共同参与, 互相推动; “合作” 是指双方相互配合 工作，共同进行; 而 “联动” 是指相互关联部件或事物, 其中一个运动或变化时, 其他也跟着运动或变化。相比之 下, “联动” 机制下的双方关系更加紧密、响应更加迅速。
潍坊学院与潍坊市教育局在签订共建协议基础上, 在 以淮坊市副市长为组长的基地建设领导小组的领导下, 从 以下四个方面进行了校地联动机制的实践和探索。

\section{1 建立行政推进联动机制}

在我国, 行政推动的力量是巨大的。为此, 我们把建 立行政推进联动机制作为体制和机制建设的首要内容, 探 索校地 “三方” (高校、教育行政主管部门和中小学校) 行 政推进联动机制。

\subsection{1 推进 “三方” 相互挂职}

“三方” 相互挂职是指高校派出管理人员和教师, 到 教育行政主管部门和中小学校担任相关职务, 教育行政主 管部门和中小学校也派出相关人员到高校挂职。“三方” 相 互挂职是实现管理联动的基础。基地建设以来, 学校先后 派出了 8 人到基础教育职能部门和中小学学校挂职, 协助 分管基础教育、教师教育及中小学校教学工作等。同时, 潍坊市教育局也派出教科院副院长、基教科和教师教育科 副科长等人, 到教师教育学院挂职, 协助分管基础教育研 究、学生实践环节等教育教学工作。“三方” 相互挂职, 不 仅使校地增进了了解, 密切了关系, 更为重要的是在校地 联动方面真正实现了 “一动均动、迅速响应”, 使共建在行 政管理人员体制方面得到了保障。

\subsection{2 成立校地共建工作室}

有了管理人员体制方面的保障, 校地共建工作要实现 常态化, 必须组建一个实现校地联动的枢纽机构。基地成 立了漼坊市教育局与潍坊学院校地共建工作室, 由市教育 局分管副局长负责, 聘请专兼职工作人员, 负责统筹潍坊 市教师继续教育、中小学骨干校长培训、师范生实习、就 业及共建重点学科和精品课程等日常管理工作。校地共建 工作室的成立, 使校地共建在机构设置上得到了保障。

\subsection{3 成立校地共建项目机构}

在校地共建工作室基础上，基地还以项目方式与基础 教育联合成立若干工作机构, 如 “潍坊市中小学生成长导 航站”、“专家工作室” 等, 实现服务基础教育工作制度化、 便利化。成立于 2008 年的 “淮坊中小学生成长导航站”, 由潍坊学院心理专家带领全市中小学心理骨干教师, 开展 对青少年心理援助、中小学生心理健康教育研究、指导学 校建立心理咨询室等工作。“专家工作室” 是指高校资深教 师在中小学设立的项目工作室, 主要任务是深入中小学教 育研究, 开展教师培训, 为中小学教师的专业成长和发展 提供智力支持和指导等。 


\section{2 建立教学研究联动机制}

教学研究联动机制的建立是推动校地共建、实现教师 教育一体化的重要条件和基本保障。为此, 我们以 “资源 共享、优势互补、组建团队、打造精品” 为目标, 积极探 索校地联动研究机制。

\subsection{1 共建重点学科}

校地共建的重要任务是整合和共享教师教育资源, 充 分发挥校地名师优势是关键。在校地共建工作室的协调下, 教师教育学院与潍坊市教科院共同承担了潍坊学院 “课程 与教学论” 重点学科建设, 共同组建了四个方向的研究团 队, 其中聘请了中小学名师名校长、教研员等作为重点学 科的核心成员。重点学科建设, 将高校教师教育改革和基 础教育教学改革紧密结合了起来, 为实现教师教育一体化 提供了有效的平台和载体。

\subsection{2 启动基地研究项目}

基地研究项目是指为围绕教师教育基地建设的联合研 究项目, 包括校地合作、学校领导和管理体制、教师队伍、 教学条件、课程教学与管理、教师培训、基地创新与特色 等方面的内容。以教师教育基地名义, 教师教育基地共建 工作室发布立项书, 面向高校和中小学校就基地建设的主 要任务开展立项, 促进教师教育研究成果的应用, 促进教 师专业发展。立项层次相当于市厅级项目, 立项研究时间 以 1-2 学期为宜, 最多不超过 4 个学期, 提倡教师 “小题 大做、小题快做”。

\subsection{3 联合开展网上教研}

充分利用现代教育技术和潍坊市中小学教研网络平 台, 联合开展网上教研。潍坊学院各专业学科教学法教师 加入到了市教科院教研队伍, 与相关学段的多名教研员、 学科骨干一起, 组成学科虚拟教研组, 随时在网上开展集 体备课、说课、网上研讨、同课异构、听课评课等教研活 动。这一举措让所有教学法教师能够及时参与到基础教育 教学改革研究中, 不仅促进了教育资源共享, 也促进了教 师的专业发展。

\section{3 建立培养培训联动机制}

培养培训联动机制的建立是校地共建联动机制的关 键, 也是校地共建最主要的内容, 直接关系到教师教育一 体化的目标能否真正落实和实现。为此, 我们以 “分工明 确、优势互补、资源共享、合作共赢” 为目标, 探索和构 建培养培训联动机制。

\subsection{1 共建 “学科” 教师专业发展学校}

与国内多数的教师专业发展学校不同, 我们以承担教 师教育的二级学院牵头, 根据学科特点, 各遴选 1-2 所具 有学科优势中学作为教师专业发展学校。各二级学院派出 一名副院长或教研室主任, 兼任该校教学副校长, 聘请该 校学科骨干教师兼任学生导师, 从大三开始, 每个导师指 导 10 名左右的学生, 学生在见习和实习期间以及校内课余 时间, 可以协助导师从事班级管理、开展学科教学及学生 作业批改与辅导等工作。该学科教师同时也走进高校, 与 学科教学法教师一起开展教研、教学评价等活动, 共同提 高教育教学质量。目前, 基地已经遴选了 20 多所教师专业 发展学校, 逐步替代了以前实习基地学校的模式。

\subsection{2 共建教师培训基地学校}

教师培训是教师教育基地的重要任务。为加强教师教 育培训基地建设, 在校地共建工作室安排下, 从全市学校 中遴选 10 所中小学, 授牌山东省潍坊学院教师教育基地培 训学校。基地学校每年根据自己优势, 向校地共建工作室 申报培训项目, 与淮坊学院共同完成省级、市级骨干教师 的培训。目前已圆满完成初中体育、小学音乐、特殊教育、 综合实践活动四个学科全省和全市骨干教师的培训任务。

\subsection{3 开展名师成长行动教育}

为总结名师成长规律, 发挥名师的教育作用, 基地开 展了 “潍坊市名师成长研究”, 并以此为基础, 在师范生中 开展了 “四段式” 名师成长教育行动。组织老师带领学生, 在四年中利用教育见习、教育调研、教育实习等环节, 结 合《教育学》、《心理学》、《名师成长研究》和《教师职业 生涯规划》等课程学习, 分四个阶段对基础教育名师开展 跟踪研究, 了解未来教师职业特点, 把握教师专业成长和 职业生涯发展的特点与规律, 深入探究名师成长的模式、 机制、规律等问题, 从而为坚定教师教育专业思想, 明确 努力方向, 为将来成为名师奠定坚实的基础。

具体包括以下四个阶段: (1)与名师的对话一一名师成 长个案研究 (第 2-3 学期); (2)对名师的反思——我身边名 师的教育故事与经历 (第 4-5 学期); (3)我的名师之路-一 教师职业生涯规划 (第 5-6 学期); (4)跟踪名师成长——“影 子学习”, 与名师共成长 (第 6-8 学期)。

\section{3. 校地联动机制构建的成效与反思}

\section{1 校地联动机制构建的主要成效}

校地联动机制的建设和实践, 基本解决了校地共建中 最关键、最艰难的问题, 扫除了实现教师教育一体化的主 
要障碍, 其效果已经显现, 主要表现在以下三个方面。

3.1.1 初步形成了教师教育 “学科-专业-课程” 共建共享的 人才培养机制

通过整合基础教育和校内教师教育资源, 共建 “课程 与教学论” 重点学科, 共建共享教师教育实验实训中心, 带动和支持了全校整个个教师教育本科专业的建设, 各教 师教育专业资源共享, 优势互补, 合作加强课程建设, 对 专业课程和教师教育模块课程进行联动教改, 优化教学内 容, 把人才培养质量落到实处。

\subsection{2 初步形成了校地 “三方联动” 的校地共建共赢培养和 培训机制}

通过行政管理、教育研究、培养培训三个联动机制的 建设, 实现了 “双向延伸” 的培养培训一体化机制, 即基 础教育提前参与准教师培养, 高校延伸服务基础教育, 促 进了师范生的培养和在职教师的专业发展。

\subsection{3 初步形成教师教育专业学生 “四段式” 名师成长行动 研究模式}

联合基础教育名师, 把教育模块课程学习与专业见习、 实习、调查等环节结合, 让学生在行动中体验、感悟、反 思教育, 研究名师, 学习名师, 为将来成为名师打下坚实 基础。

\subsection{4 搭建了师生共同成长的平台}

通过三个机制的建设, 促进了校地教育资源的整合和 共享。大学将中小学教育改革的实践成果引入教师教育课 程中去, 邀请中小学名师走进大学校园, 担任本科生的指 导教师, 为本科生讲授教材教法、学科教学论、案例教学、 新课程改革、中小学教育教学发展动态等课程。大学教师 走进中小学校, 服务、指导基础教育的教学教学改革, 为 教师的专业成长和发展提供智力支持和帮助。

\section{2 反思与需要深入解决的问题}

我们的实践探索才刚刚起步，仍需继续深化建设。

一是校地共建联动机制的协调性、一体性、稳定性需 要加强。高校和基础教育的工作重心不同, 协调中必然有 冲突, 如何解决好联动机构、联动管理队伍的稳定性是一 个关键; 同时由于队伍的整体素质 (包括管理素养、理论 素养、实践活动能力等) 有待进一步提升和加强。

二是高校教师服务基础教育和经济社会的能力叒待提 高。由于高校教师教育长期与基础教育脱节, 高校教育教 学重理论、轻实践、轻应用, 教师服务基础教育和经济社 会的能力亟待提高, 也直接影响校地共建联动机制形成的 效率和效果。

三是校地共建联动机制的形成是一个长期、复杂的建 设过程, 决定着教师教育基地建设的成败, 今后还需要在 常态化、制度化等方面加强建设, 促进基地建设的资源、 师资、成果的共享, 重建教师教育新体系。

\section{参考文献(References)}

[1] Xu Li: Research on On-the-job Training Problem of Teachers in Our Country, Teacher Education Research 2004(7).

[2] Lu Bingyan: Integration: Reflection and Practice on Teacher Education Reform, East China Normal University Press 2000.

[3] Yi jidong, Liu Liusheng: Research on Teacher Education Reform and Development, Yunnan People's Publishing House 2007.

[4] Zhang Guixin: Establishment of a System of Integrated Education for In-and-pre-service Normal Universities Teachers, Chinese Higher Education 2001(17).

[5] Zhong Binglin: Development of Teacher Education and Transformation of Normal Colleges, Educational Research 2003(6).

[6] Xu Li: Research on On-the-job Training Problem of Teachers in Our Country, Teacher Education Research 2004(7). 